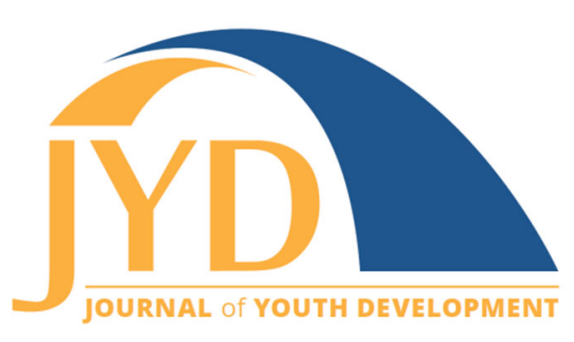

http://jyd.pitt.edu/ | Vol. 15 Issue 5 DOI 10.5195/jyd.2020.921 | ISSN 2325-4017 (online)

\title{
Resource Review: Project Learning Tree PreK-8 Environmental Education Activity Guide
}

\author{
Rachel Bayer \\ University of Maryland \\ rjbayer@umd.edu
}

\begin{abstract}
Given growing environmental concerns such as climate change, identifying high-quality environmental education materials that can be used by youth development professionals to meet their educational goals is critical. The Project Learning Tree (PLT) PreK-8 Environmental Education Activity Guide is designed for individuals to develop the knowledge and skills needed to make informed decisions and take action on environmental issues. The curriculum has activities that youth development professionals can use to teach a wide variety of environmental topics ranging from air quality to food chains, habitats, recycling, and watersheds, to name a few. In addition, as a high-quality environmental education curriculum, the guide assists those who desire to develop skills in youth such as critical thinking, communication, and civic engagement. This review of the PLTPreK-8 Environmental Education Activity Guide provides an overview of the curriculum and how the activities are structured and outlines considerations for its use by youth development professionals.
\end{abstract}

Key words: environmental education, Project Learning Tree

\section{Environmental Education and Positive Youth Development}

The Tbilisi Declaration of 1977 defines environmental education (EE) as the learning process that increases people's knowledge and awareness about the environment and its associated challenges, develops the necessary skills and expertise to address these challenges, and fosters attitudes, motivations, and commitments to take responsible action (Project Learning Tree, 2019). Research suggests that EE can serve as a potential resource for youth development professionals looking to advance environmental learning while achieving youth development goals.

(cc) EY New articles in this journal are licensed under a Creative Commons Attribution 4.0 License. This journal is published by the University Library System, University of Pittsburgh and is cosponsored by the University of Pittsburgh Press. The Journal of Youth Development is the official peer-reviewed publication of the National Association of Extension 4-H Youth Development Professionals and the National AfterSchool Association. 


\section{Resource Review: Project Learning Tree}

Garst (2018) developed a conceptual framework outlining how high-quality EE and naturebased experiences can serve as a vehicle for positive youth development by aligning the four youth development domains (physical, intellectual, emotional, and social) to outcomes from nature-based experiences, such as increased physical activity, academic performance, social interactions, and resiliency. This framework serves as the foundation for a nature-based youth development model, which ties the characteristics found in high-quality nature experiences (social interactions, skill-building, and learning through community action) to the three main resources required for positive youth development (positive and sustained youth-adult relationships, youth skill-building, and youth involvement and leadership). Research also links the use of EE to the development of 4-H life skills, including decision-making, critical thinking, and community and civic engagement skills (Ardoin et al., 2018; Ernst \& Monroe, 2004; North American Association for Environmental Education, 2017; Schusler et al., 2009).

This research, in combination with the growing environmental concerns, such as climate change, makes identifying high-quality EE materials that can be used by youth development professionals to meet their educational goals critical. Project Learning Tree (PLT) is a national environmental education program, sponsored by the Sustainable Forestry Initiative, a nonprofit international organization. PLT provides curriculum and professional development to individuals working with or teaching youth in all 50 states (PLT, 2019). PLT offers a range of curricula materials designed for early childhood through high school audiences. The program meets the North American Association for Environmental Education Guidelines for Excellence in Environmental Education (PLT, 2019). In addition, an alignment between Hendricks's (1998) 4-H Life Skills model and the PLT PreK-8 Environmental Education Activity Guide (Project Learning Tree, 2019) suggests that using the activities with youth can help develop life skills (Bayer \& Fischer, 2019).

\section{PreK-8 Environmental Education Activity Guide Description}

PLT's PreK-8 Environmental Education Activity Guide contains 96 multidisciplinary activities that youth development professionals can use to teach about a variety of environmental topics. The guide, designed for use by both formal and nonformal educators, goes through a continuous improvement process to remain current with educational standards and trends (PLT, 2019).

The guide's conceptual framework serves as the basis for the development and structure of the activities. The conceptual framework is comprised of five themes, which are also the five sections of the guide: diversity, interrelationships, systems, structure and scale, and patterns of 
change. Each section of the guide contains between 15 and 20 hands-on and experiential learning activities that explore that conceptual framework theme. Table 1 describes the elements of each activity.

Table 1. Activity Elements and Descriptions

\begin{tabular}{|c|c|}
\hline Activity element & Description \\
\hline Activity title & Names the activity and is descriptive of the activity's content. \\
\hline Overview & Provides a brief description of the activity. \\
\hline Objectives & States the youth learning objectives for the activity. \\
\hline $\begin{array}{l}\text { Assessment } \\
\text { opportunities }\end{array}$ & $\begin{array}{l}\text { Provides guidance on how to assess students' understanding of the activity } \\
\text { concepts. }\end{array}$ \\
\hline Sidebar & $\begin{array}{l}\text { Provides information relevant to using the activity, including grade levels, } \\
\text { subjects incorporated, skills addressed, materials needed, and time } \\
\text { considerations. }\end{array}$ \\
\hline Background & $\begin{array}{l}\text { Provides information instructors need to have an understanding and perspective } \\
\text { for engaging youth around the activity's topic. }\end{array}$ \\
\hline Getting ready & Describes how to prepare for teaching the activity. \\
\hline Doing the activity & Provides step-by-step instructions for leading the activity. \\
\hline Variations & $\begin{array}{l}\text { Provides alternative procedures for doing the activity, which have similar } \\
\text { objectives to the main activity, but may appeal to different ages, learning styles, } \\
\text { or situations. }\end{array}$ \\
\hline Enrichment & Contains recommendations for ways to extend the activity's learning experience. \\
\hline $\begin{array}{l}\text { Reading } \\
\text { connections }\end{array}$ & Provides a list of children's literature that is relevant to the activity. \\
\hline Student pages & $\begin{array}{l}\text { Includes pages that can be copied for the students to complete, if needed, for the } \\
\text { activity. }\end{array}$ \\
\hline
\end{tabular}

\section{Indices}

The guide also contains a number of indices outlining the subjects (math, reading, etc.), topics (biodiversity, renewable resources, etc.), time considerations, and settings (inside, outside) for each activity. 
Resource Review: Project Learning Tree

\section{Considerations for Youth Development Professionals}

The PLT PreK-8 Environmental Education Activity Guide fits well for youth development professionals who are looking for experiential learning opportunities. Below are specific considerations for professionals interested in integrating PLT into their instruction.

- The guide is available to individuals, but they must participate in a professional development workshop, either in person or online, where they learn how to effectively use PLT activities in their teaching (see "How to Obtain"). Upon attending a training and receiving the guide, individuals can immediately integrate the activities into their educational programs.

- The hands-on activities can be done inside or outside and require materials that instructors likely already have on hand or are easily obtainable.

- Using the curriculum facilitates active participation by youth in the learning process through the integration of inquiry-based teaching and cooperative learning strategies.

- The curriculum is designed for anyone working with youth; however, its primary audience is formal classroom educators. Activities used outside of a formal classroom setting may require modification. For instance, many activities are designed for 50 minutes or multiple 50-minute periods. Youth development professionals may need to adapt activities to fit into alternative timeframes.

- The activities in the curriculum cover a wide variety of environmental topics and develop a conceptual understanding of these topics, such as composting or recycling. This makes the guide a good resource for sparking youth interest and critical thinking on a given environmental topic. However, the activities themselves do not pursue topic areas in enough depth to result in mastery of a given subject.

- The activities in the guide align well with the development of the head, hands, and heart skills from the Hendricks's (1998) 4-H Life Skills model. However, very few of the activities develop health skills, making this resource less appropriate for youth development professionals seeking to develop healthy living skills (Bayer \& Fischer, 2019).

- Youth development professionals who are new to integrating environmental education into their programs should consider identifying the intended learning outcomes for their youth and link various PLT activities together to maximize knowledge and learning gains. There are various appendices and indexes within the PLT Guide to help with this process. 
The PLT PreK-8 Activity Guide provides youth development professionals with a well-rounded curriculum for engaging youth ages 5 to 14 in learning about the natural and built environment. Youth development professionals can use the guide's activities to develop the skills youth need, such as critical thinking and civic engagement, to make informed decisions and take action to improve their local community and environment.

\section{How to Obtain}

As previously noted, individuals must attend a professional development workshop to receive the guide. In-person workshops range from $\$ 0$ to $\$ 50$. An online workshop costs $\$ 40$ and includes an e-book (and an option to purchase the printed guide for \$24.99). Find out more at https://www.plt.org/trainings/attend-a-training/.

\section{References}

Ardoin, N., Bowers, A., Roth, N., \& Holthuis, N. (2018). Environmental education and K-12 student outcomes: A review and analysis of research. The Journal of Environmental Education, 49(1), 117. https://doi.org/10.1080/00958964.2017.1366155

Bayer, R., \& Fischer, K. (2019). Correlating Project Learning Tree to 4-H life skills: Connection and implications. Journal of Extension, 575), Article 5TOT6. https://joe.org/joe/2019october/tt6.php

Ernst, J., \& Monroe, M. (2004). The effects of environment-based education on students' critical thinking skills and disposition toward critical thinking. Environmental Education Research, 10(4), 507-522. https://doi.org/10.1080/1350462042000291038

Garst, B. A. (2018). Nature and youth development. In P. A. Witt \& L. L. Caldwell (Eds.), Youth development: Principles and practices in out-of-school time settings (pp. 241-268). SagamoreVenture.

Hendricks, P. A. (1998). Developing youth curriculum using the targeting life skills model: Incorporating developmentally appropriate learning opportunities to assess impact of life skill development. Iowa State University.

North American Association for Environmental Education. (2017). Community engagement: Guidelines for excellence. Author. https://cdn.naaee.org/sites/default/files/community engagement guidelines for excellence.pdf

Project Learning Tree. (2019). PreK-8 environmental education activity guide (13 ${ }^{\text {th }}$ ed.). Sustainable Forestry Initiative. 
Journal of Youth Development | http://jyd.pitt.edu/ | Vol. 15 Issue 5 DOI 10.5195/jyd.2020.921

Resource Review: Project Learning Tree

Schusler, T., Krasny, M., Peters, S., \& Decker, D. (2009). Developing citizens and communities through youth environmental action. Environmental Education Research, 15(1), 111-127. https://doi.org/10.1080/13504620802710581 